\title{
Explaining G20 and BRICS Compliance
}

\author{
M. Larionova, M. Rakhmangulov, A. Shelepov
}

Marina Larionova - Doctor of Political Science, PhD in Philology, Head and Leading Research Fellow of the Center for International Institutions Research, Russian Presidential Academy of National Economy and Public Administration; 11 Prechistenskaya naberezhnaya, 119034 Moscow, Russian Federation; E-mail: larionovamv@ranepa.ru

Mark Rakhmangulov - Researcher of the Center for International Institutions Research, Russian Presidential Academy of National Economy and Public Administration; 11 Prechistenskaya naberezhnaya, 119034 Moscow, Russian Federation; E-mail: rakhmangulov-mr@ranepa.ru

Andrey Shelepov - Researcher of the Center for International Institutions Research, Russian Presidential Academy of National Economy and Public Administration; 11 Prechistenskaya naberezhnaya, 119034 Moscow, Russian Federation; E-mail: shelepov-av@ranepa.ru

This article explores the internal and external factors influencing the compliance performance of the Group of 20 (G20) and the BRICS group of Brazil, Russia, India, China and South Africa. The authors start with an overview of the G20 and BRICS compliance patterns using comparative data on the number of commitments made by the two institutions, the level of institutional compliance, and distribution of commitments and compliance across issue areas. G20 compliance is traced since the leaders' first 2008 summit in Washington. The BRICS compliance performance record includes data since the third standalone summit in Sanya in 2011.

The study then takes stock of compliance catalysts embedded in the summits' discourse: priority placements, numerical targets, timelines, self-accountability pledges and mandates to implement or monitor implementation. The authors review trends in the use of catalysts and issue areas and identify commonalities and differences.

The analysis then turns to external causes of compliance and focuses on demand for collective actions and members' collective power to respond and deliver on their pledges. Here the study explores whether the self-accountability mechanisms created by the institutions in response to the demand for effectiveness and legitimacy facilitate compliance.

The article concludes by highlighting catalysts, causes of compliance and their combinations with the greatest power to encourage implementation, explaining trends in G20 and BRICS compliance performance.

The data sets on G20 and BRICS differ in terms of scale. The G20 data set contains 1,511 commitments of which 114 have been monitored, and the BRICS data set contains 231 commitments of which 23 have been monitored.

Key words: global governance, informal summit institutions, engagement models, international organizations, efficiency, legitimacy, rational choice theory, G20, BRICS, APEC

\section{Introduction}

As informal summit institutions, the Group of 20 (G20) and the BRICS group of Brazil, Russia, India, China and South Africa are often criticized for being illegitimate and ineffective. ${ }^{1}$ There are many dimensions and definitions of legitimacy and effectiveness. Legitimacy can

${ }^{1}$ An informal summit institution is an international institution with limited membership, relatively low bureaucracy and reliance on open, flexible and voluntary approaches, and whose heads of government meet regularly. The leaders' meetings stand at the pinnacle of such international or regional arrangements, which involve many actors operating according to established procedures on two levels: domestic and international. Commitments contained in the collectively agreed documents are not legally binding but their implementation 
be defined as the acceptability of the institution, its rules, decisions and activities to members, non-member states and international institutions. The input dimension of legitimacy includes the three indicators of decision-making (decision making mode), transparency (openness and accountability, both external and internal, ex-ante and ex-post) and inclusiveness (number of member states, number of outreach countries invited, number of international organizations involved) (see [Gnath, Mildner and Schmucker, 2012]). The output dimension of legitimacy includes the three criteria of commitments (concrete and publicly agreed decisions), delivery on the commitments (compliance performance) and outcomes (policy changes at the international or national level). Effectiveness correlates closely with legitimacy, especially its output dimension. Effectiveness is understood as an institution's capability to agree on collective commitments, deliver on the pledges made and exert policy changes that help solve collective problems (see [Gnath, Mildner and Schmucker, 2012]).

This article focuses on effectiveness as the capacity of the G20 and BRICS to deliver on the commitments made by the leaders at the summits. It explores, compares and explains the compliance performance of both groups.

\section{The Analytical Framework}

The methodology used in the study uses the methodology developed and applied by the G7 Research Group since 1996 to monitor compliance. With the advent of G20 at the leaders' level, the methodology was refined to assess G20 compliance performance by the International Organizations Research Institute of the National Research University Higher School of Economics (IORI HSE) and G20 Research Group. Since 2011 it has been fine-tuned by all three teams to track BRICS delivery on the collective decisions.

\section{Assessing Compliance with Commitments}

The use of a single analytical framework ensures consistency across members, commitments and presidencies and allows comparative assessments of G7/8, G20 and BRICS performance.

Commitments are selected for analysis from the documents issued by leaders at the summits. Commitments are defined as discrete, specific, publicly expressed, collectively agreed statements of intent; they are a "promise" or "undertaking" by summit members that they will undertake future actions to move toward, meet or adjust to meet an identified welfare target [Kirton, Kokotsis, Guebert et al., 2016].

Compliance assessment deals with priority commitments from each G7/8, G20 and BRICS summit. Priority commitments are those that best capture what the summit as a whole did on the decision-making dimension of its global governance. Due to the large number of commitments that appear in the leaders' documents (for instance, 281 commitments were adopted at the St Petersburg G20 summit), it is difficult to assess every commitment for compliance. Therefore, only commitments that reflect the essence of the summit documents in a reasonably representative way are chosen for compliance analysis. Thus, the selection represents the priorities of the summit and replicates the breakdown of issue areas and the proportion of commitments in each one. The sample is also balanced to allow for comparison with past and future summits. Priority commitments should be chosen that apply to various subsets of countries within the group. The ability to commit fully to the commitment within a year is taken

is stimulated by peer pressure. Among such bodies engaged in global and regional governance are the Group of Seven/Eight (G7/8), the G20, the BRICS and the Asia Pacific Economic Co-operation Forum. 
into account to ensure relevance of the results. The commitments should meet some additional criteria, such as performance measurability and significance as identified by the research team and relevant experts [Kirton, Kokotsis, Guebert et al., 2016].

Compliance is understood as national governments' actions geared toward the domestic implementation of the necessary formal legislative and administrative regulations designed to execute summit commitments. Compliance is assessed according to the criteria of official reaffirmation of a summit commitment, internal bureaucratic review and representation, budgetary and resource allocations made or changed, and new or altered programmes, legislation and regulations.

This methodology uses a three-level measurement scale. Full or almost full compliance with a specific commitment is assigned a score of +1 . A score of -1 indicates complete or nearly complete failure to implement a particular commitment. A score of 0 is given for inability to deliver or work in progress. Inability to deliver is a situation referring to factors that impede implementation and cannot be controlled by the government of a state assessed for compliance. Work in progress describes initiatives that have been launched but have not yet been completed by the time of the next summit, and whose results therefore cannot be measured and assessed. Compliance scores of -1 and 0 do not necessarily imply an unwillingness to comply. In some cases policy actions need multiple compliance cycles (that is, the periods between summits) to be fully implemented and subsequently measured.

Once the individual compliance scores are determined, averages are calculated for each commitment and member, and for the summit as a whole. These scores can range between -1 and +1 .

The analysis draws on the data presented in the G20 and BRICS compliance reports prepared by the G20 Research Group and the IORI HSE for the summits between 2008 and 2014. ${ }^{2}$ BRICS compliance data are available only for the summits between 2011 and 2014. ${ }^{3}$

\section{Taking Stock of Compliance Catalysts}

\section{Analyzing Catalysts}

The analysis focuses on specific approaches of the G20 and the BRICS and the trends emerging in their use of catalysts in their commitments. Compliance catalysts are words, phrases or factors that are embedded in and guide a commitment. They provide instruction on how to implement, proceed or comply with the commitment [Kirton, Kokotsis, Guebert et al., 2016]. The analysis starts with an overview of compliance catalysts embedded in the summits' discourse, and then identifies and systemizes the catalysts in all commitments: priority placement, numerical targets, timelines, self-accountability pledges, references, and mandates to implement or monitor implementation within G20 or BRICS structures.

This study differentiates between self-accountability pledges built into a concrete commitment (a commitment catalyst) and those pertaining to a wide range or the full set of G20 commitments (self-accountability commitments). Both types are expected to exert an impact on G20 compliance performance, although the influence of a catalyst is assumed to be limited to the specific commitment, while self-accountability of a more broad sort is deemed to enhance the institution's compliance performance in responding to demands of external stakeholders for effectiveness and transparency. An example of the broader type of self-accountability is drawn

${ }^{2}$ G20 compliance reports are available on the G20 Information Centre website at http://www.g20.utoronto.ca/compliance.

${ }^{3}$ BRICS compliance reports are available on the BRICS Information Centre website at http://www. brics.utoronto.ca. 
from the G20's 2010 Toronto Summit, where the leaders declared: "We are determined to be accountable for the commitments we have made, and have instructed our Ministers and officials to take all necessary steps to implement them fully within agreed timelines" [G20, 2010b].

The study pays special attention to G20 and BRICS engagement with international institutions and whether such engagement fosters implementation. It identifies and systemizes all cases of such international institutions' engagement in all commitments to expose any influence on G20 and BRICS performance.

The debate on the summit institutions' relationship with international organizations has mostly centred on connections between the G7/8 and multilateral organizations. Four schools of thought offer arguments on G7/8 governance through the multilateral organizations, G8 governance against multilateral organizations, G8 governance without multilateral organizations and G8 governance in alliance with the multilateral organizations [Kirton, 2010, pp. 24-27]. According to the available evidence, all four modes of governing though, governing in alliance, governing against and governing without are practised by the G20 and BRICS.

After reviewing the general trends in compliance catalysts, the study explores the monitored commitments for which data on compliance performance are available. The sample is separated into two subsets, those with and without embedded catalysts. The comparison of these subsets is intended to reveal if and how catalysts affect compliance performance.

\section{Analyzing External Causes of Compliance}

The second stage of the analysis explores external causes of compliance by focusing on demand for collective action, in the form of members' collective power to respond to demand and deliver on the pledges made.

To assess if and how demand for global governance encourages implementation, the study identifies commitments made in response to the major challenges of the period. The sample does not have any formal markers. Rather, it includes decisions selected by the authors drawing on their understanding of the urgency for collective action to resolve persistent or new risks in a certain policy area at the time of the summit. Some of these commitments are specific to the summit, reflecting changes in demand for the institution's actions. Others are present in all summit documents, reflecting the long-term nature of the challenge or the failure of the club's members to deal with the problem effectively. Compliance performance with these commitments is compared with the average compliance for all commitments with compliance scores available.

In responding to the demand for effectiveness and legitimacy, the institutions make reinforcing self-accountability commitments, for example at St. Petersburg the G20 pledged to "act together and implement all [our] commitments in a timely manner" [G20, 2013]. Such statements are typical of most G20 summits. Overarching pledges on self-accountability and the resulting mechanisms respond to pressure from the international community and create intra-institutional peer pressure to act on the collectively made decisions. This study identifies these self-accountability mechanisms and explores their effects on compliance.

\section{The Hypotheses}

The study tests two hypotheses. The first hypothesis is that catalysts built into commitments should influence the summit institutions' compliance performance. It is assumed that the degree of influence would depend on the type of the catalysts. Thus, G20 and BRICS compliance is expected to increase if the G20 or BRICS acts in engagement with international organizations in a governing-in-alliance or governing-through mode. 
The second hypothesis is that the urgency for the demand for collective actions would encourage implementation. Self-accountability mechanisms in response to pressure from external stakeholders and intra-institutional peer pressure to act on the collectively made decisions are expected to enhance compliance performance.

\section{Explaining Trends in G20 and BRICS Compliance Performance}

\section{Trends in G20 and BRICS Commitments}

Although the BRICS is becoming increasingly important in global governance, it made an average of 39 commitments per summit, far behind the G20's average of 168 commitments in 2008-2014 (see Figure 1). The trend for the G20 is mixed. While remaining relatively stable in 2008 and 2009, its average dropped at the 2010 Toronto Summit, but increased again at Seoul later the same year. It then almost doubled in 2011, fell in 2012, went up again in 2013 and decreased again in 2014. For the BRICS, between 2009 and 2014 the number of commitments maintained a steady, positive trend. However, at its peak of 68 in 2014 it was still almost three times lower than the G20's average.

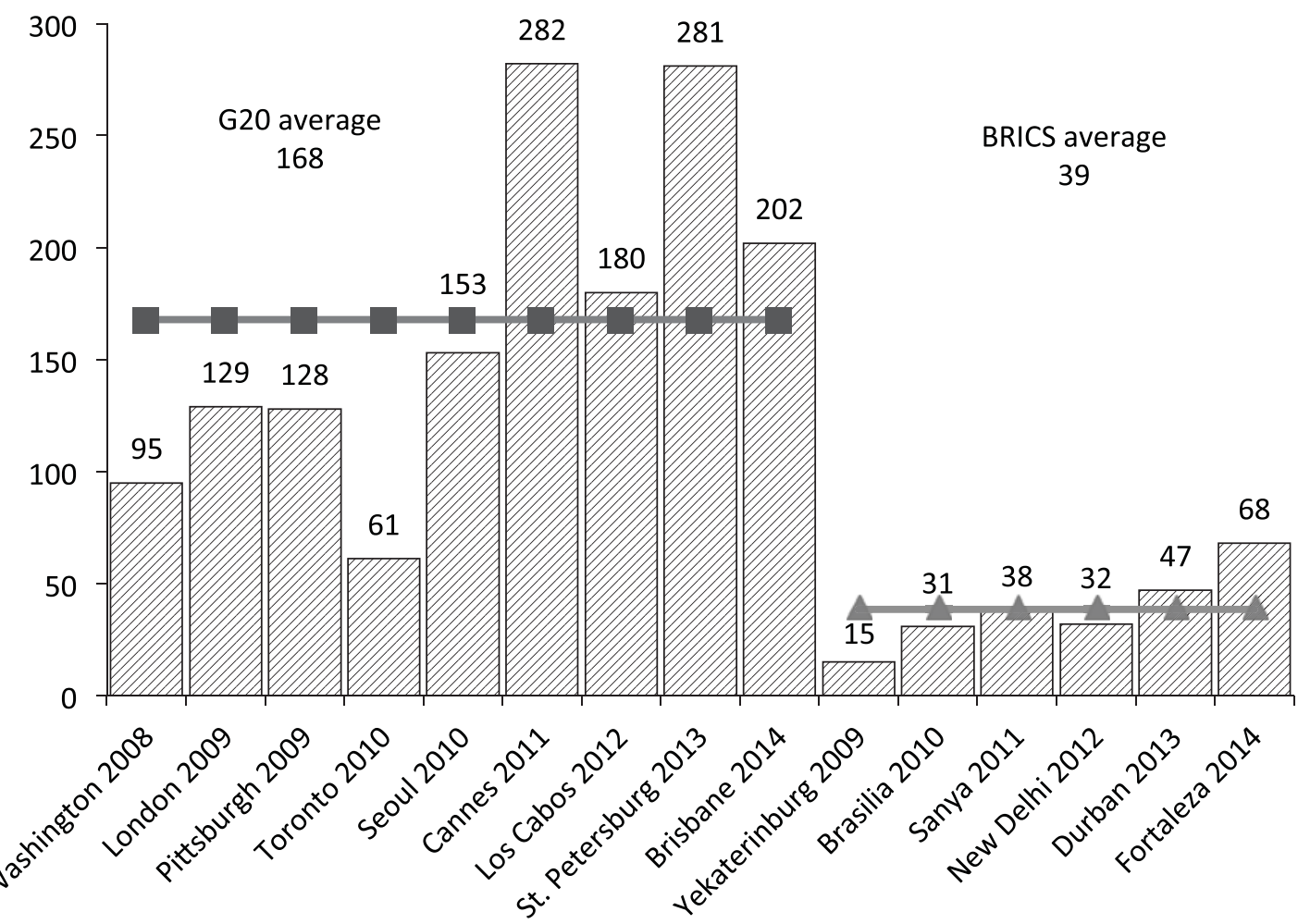

Figure 1: G20 and BRICS commitments, 2008-2014

The distribution of G20 and BRICS commitments across policy areas reflects the core missions of the institutions (see Table 1). True to its mission as the key global forum for economic cooperation, the G20 focuses on macroeconomic policy and financial regulation, including the recurring commitments on growth-friendly fiscal consolidation, flexible exchange rates, structural reforms, the Basel standards for banking capital and liquidity, over-the-counter 
derivatives and systemically important financial institutions. It also consistently makes commitments on resisting protectionism in trade and investment, and reforming global financial institutions. Its commitments from other areas aim to address climate change, phase out inefficient fossil fuel subsidies, and fight crime and corruption. On development it focuses on such issues as infrastructure investment, social protection floors, food security and sustainable agriculture, remittances, and financial inclusion.

As a group of major emerging economies, the BRICS concentrates on practical cooperation and concrete measures to stimulate the economic recovery as reflected in a large share of trade and development commitments. Decisions on international cooperation and reform of international financial institutions (IFIs) each constitute about 10\%, reflecting the members' desire to modernize the governance architecture to reflect the increasing weight of emerging economies in the world economy. At the same time, the priorities of each BRICS presidency substantially influence the breakdown of commitments. For instance, commitments made during the Russian presidency in 2009 focused mainly on energy and agriculture. Brasilia in 2010 retained energy issues as a priority and added development. The 2011 summit in Sanya resulted in numerous commitments on international cooperation and climate change. The 2012 New Delhi and 2013 Durban summits addressed regional security, and Durban also dealt with development issues, regional integration and infrastructure development. The 2014 Brazilian presidency focused on macroeconomic and socioeconomic issues, while also paying attention to traditional BRICS priorities, including IFI reform and international cooperation.

Table 1: G20 and BRICS Commitments by Issue Area, 2008-2014, \%

\begin{tabular}{|l|c|c|}
\hline \multicolumn{1}{|c|}{ Issue area } & G20 & BRICS \\
\hline Macroeconomic policy & 21.8 & 5.9 \\
\hline Financial regulation & 20.7 & 4.0 \\
\hline Development & 9.5 & 10.0 \\
\hline Reform of international financial institutions & 8.8 & 9.2 \\
\hline Trade & 7.4 & 10.9 \\
\hline Energy & 5.5 & 11.9 \\
\hline Accountability & 5.0 & 0.4 \\
\hline Labour and employment & 4.5 & \\
\hline Crime and corruption & 4.0 & 1.0 \\
\hline Climate change & 3.0 & 5.3 \\
\hline Food and agriculture & 2.9 & 4.5 \\
\hline International cooperation & 1.8 & 10.4 \\
\hline Health & 1.8 & 1.2 \\
\hline Infrastructure & 1.8 & \\
\hline Socioeconomic policy & 1.2 & 5.7 \\
\hline Environment & 0.2 & 0.2 \\
\hline Green growth & 0.2 & \\
\hline Regional security & & 7.9 \\
\hline Science and education & & 2.6 \\
\hline
\end{tabular}




\begin{tabular}{|l|c|c|}
\hline \multicolumn{1}{|c|}{ Issue area } & G20 & BRICS \\
\hline Terrorism & & 2.2 \\
\hline Natural disasters & & 2.1 \\
\hline Culture & & 1.3 \\
\hline Human rights & & 1.3 \\
\hline Information and communication technologies & & 1.1 \\
\hline Sport & & 0.5 \\
\hline Non-proliferation & 100.0 & 0.4 \\
\hline Total & & 100.0 \\
\hline
\end{tabular}

Overall, although commitments on development, trade, energy, agriculture, macroeconomic policy and financial regulation are regularly made by both institutions, the G20 and BRICS each has its own core agenda, as reflected by the general breakdown of commitments. However, the distribution of commitments depends not only on the mission and capabilities of the particular institution, but also on the priorities of the presidencies and the demand for global governance.

\section{Delivering on Commitments}

The G20 compliance performance is mixed so far (see Figure 2). After the Toronto Summit, when compliance stood at a score of +0.38 (higher than +0.22 for the Pittsburgh Summit and the London results of +0.34 , but lower than the Washington average of +0.59 ), the figure rose to +0.50 in Seoul, +0.55 in Cannes and +0.57 in Los Cabos. However, it dropped to +0.44 in St. Petersburg and further to +0.42 at Brisbane. The G20 average compliance score for all summits amounts to +0.45 .

The average compliance score for BRICS $(+0.41)$ is similar to that of the G20. However, BRICS compliance data is available only for four summits, with fluctuations in average compliance score across them, compared to data for nine G20 summits. The BRICS average was relatively high for Sanya and Durban ( +0.48 for both summits), while the New Delhi figure of +0.28 was half that score, and the +0.40 registered in Fortaleza also was a drop compared to the previous summit.

Thus, despite the growing number of commitments made by the G20, its compliance performance improved by the Los Cabos Summit and remained at a relatively high level afterward. The reasons for this trend include a persistent demand for the G20 to act and for its effectiveness and legitimacy, as well as the emergence of self-accountability mechanisms. However, BRICS compliance scores fluctuate from summit to summit, which raises a question about if and how self-accountability affects performance, given that the BRICS has no self-accountability mechanisms.

\section{Compliance by Issue Area}

Given the different nature of the G20 and BRICS, priority commitments selected for assessing compliance represent different policy areas. However, the data allow comparing compliance scores in the main policy areas with the caveat that the BRICS compliance track record is shorter.

In general, delivery on commitments was higher in the areas at the core of the institutions' agenda (see Table 2). The G20 delivered better on macroeconomic and employment commit- 


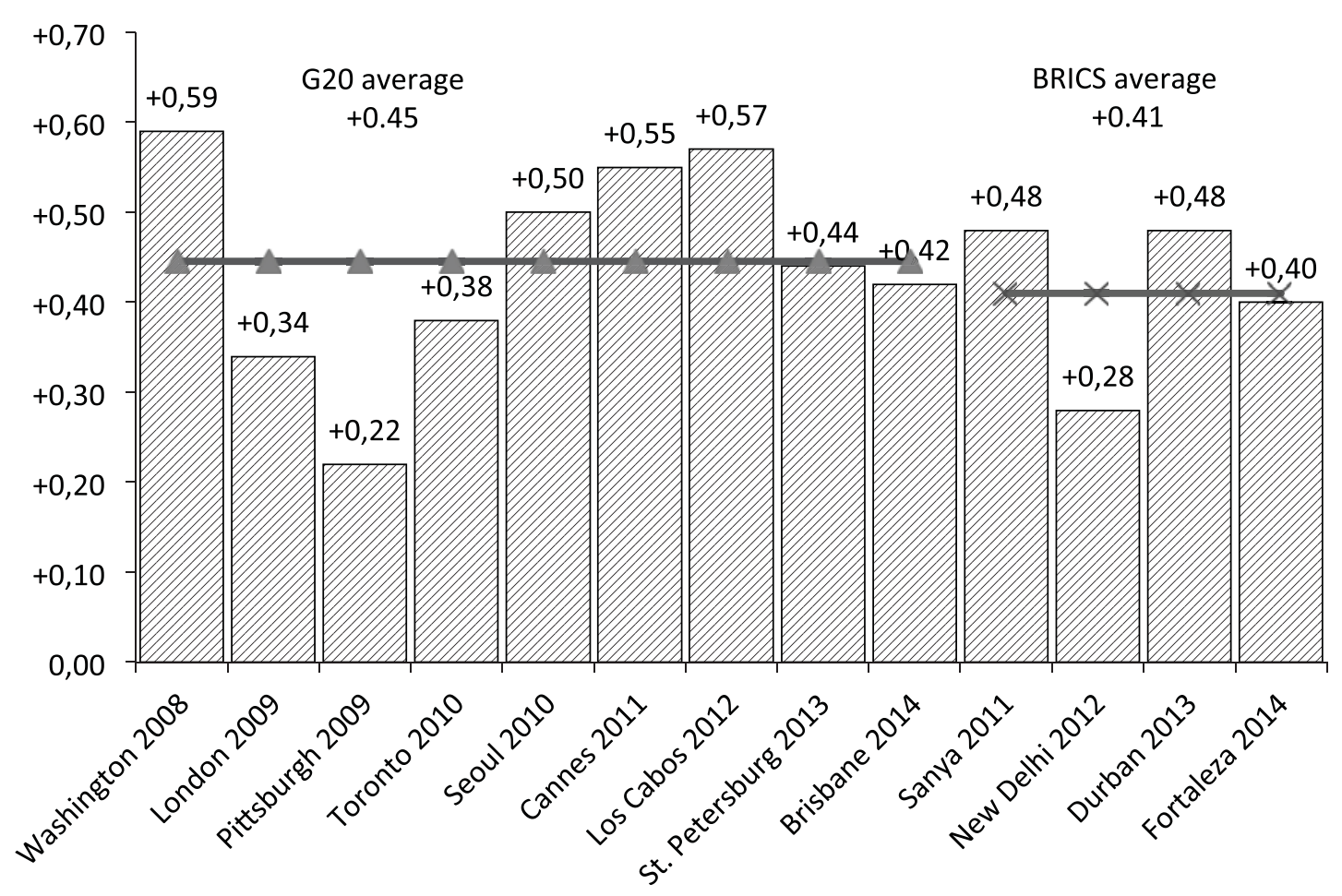

Figure 2: G20 and BRICS Compliance, 2008-2014

ments, including those related to fiscal consolidation, flexible exchange rates and policies to cut unemployment. Some commitments that were reiterated at each summit, as in the areas of trade (antiprotectionism) and development, remained largely unaddressed. The BRICS achieved moderate success in many of the policy areas examined, with the highest scores on anticorruption (strengthening international cooperation to combat bribery), development (supporting infrastructure investment and industrial development in Africa) and energy (promoting clean technologies). It had less success on trade, macroeconomic policies, IFI reform and regional security. Compliance in some areas lagged behind in both institutions. These areas include trade, where most G20 economies and all the BRICS members failed to fight protectionism successfully, and development and climate change, where progress in implementing coordinated policies was limited.

Thus, average compliance performance across issue areas is mixed for the G20 and BRICS. However, there is a common trend. Delivery on core priorities increased from summit to summit, but compliance with new commitments proved challenging, and implementing decisions that are not in line with some members' national interests, such as trade, was often poor as well.

To sum up, the analysis of compliance revealed that G20 compliance performance generally remained slightly higher than BRICS compliance performance, with the G20 averaging +0.45 over the period of 2008 to 2014 and the BRICS averaging +0.41 over the period of 2011 to 2014. Both institutions tended to agree on a growing number of commitments in different areas. Nonetheless, the G20 and the BRICS each had its own core agenda and compliance with its priority commitments was generally higher than with other commitments. 


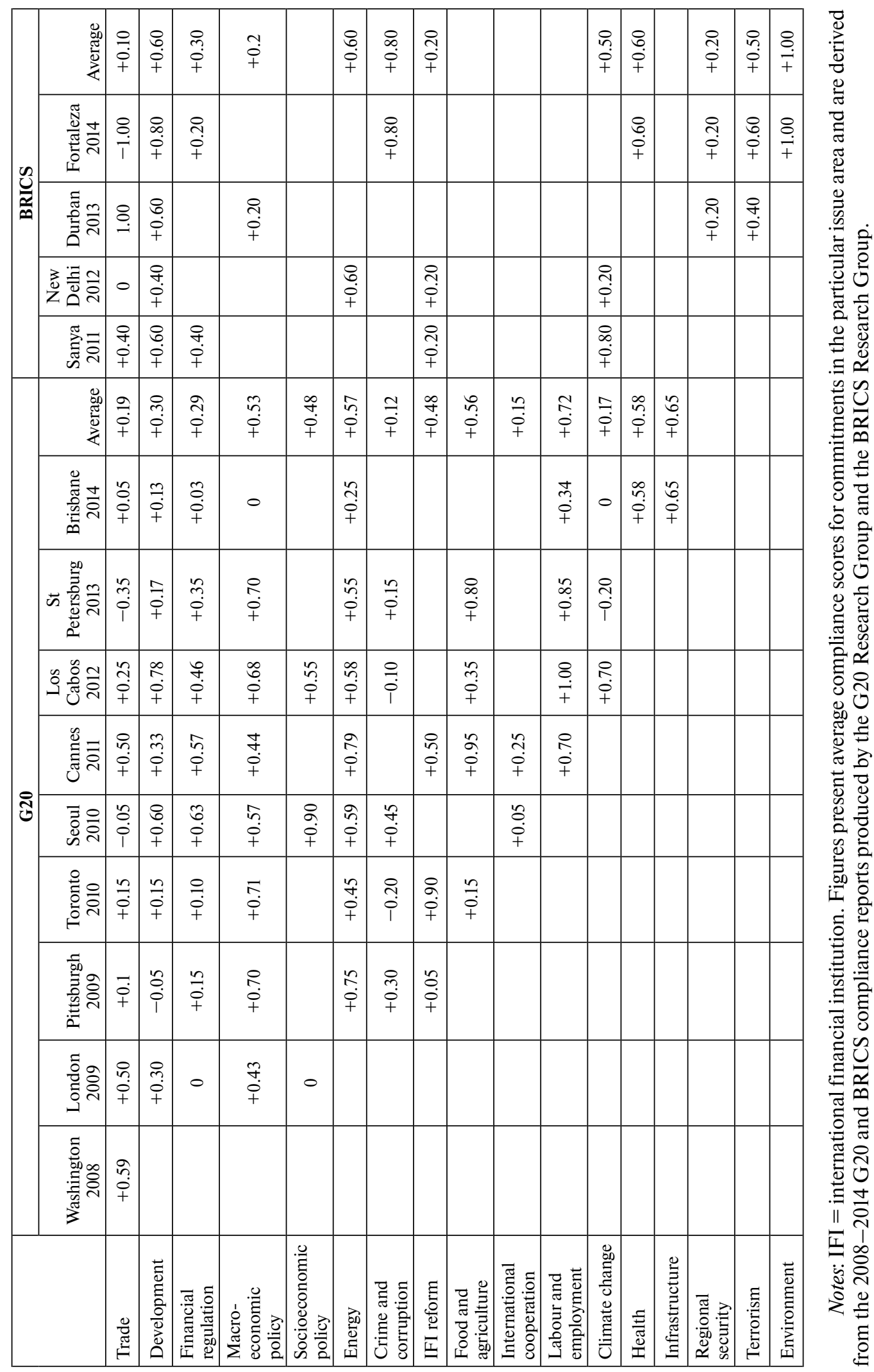




\section{Compliance Catalysts: Trends in G20 and BRICS Use of Catalysts}

Given the difference in the total number of G20 and BRICS commitments as well as the number of commitments made at different summits, relative indicators were used for comparative analysis. Interestingly, the proportion of commitments with catalysts in G20 and BRICS discourse is reasonably similar, with $37.7 \%$ for the G20 (569 of 1,511 commitments) and 41.1\% for the BRICS (95 of 231 commitments). However, the opposite trend is observed: although the proportion of $\mathrm{G} 20$ commitments with catalysts decreased almost constantly since the 2010 Toronto Summit and dropped to $23.8 \%$ at the 2014 Brisbane Summit, the proportion of BRICS commitments increased without interruption until the 2014 Fortaleza Summit, when it decreased slightly to 51.5\%. In 2012, for the first time, the BRICS outperformed the G20 in terms of catalysts: $31.7 \%$ at the G20 Los Cabos Summit and 43.8\% at the New Delhi Summit. Future trends are difficult to predict, but with the substantial proportion of commitments with catalysts made by the BRICS, it is likely to stabilize, rather than increase further.

Table 3: G20 Commitments with Catalysts

\begin{tabular}{|c|c|c|c|c|c|c|c|c|c|c|}
\hline & 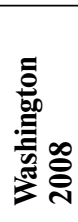 & 总。 & 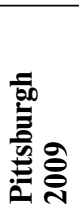 & 을을 & 离 & 总 & 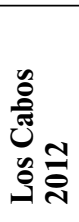 & 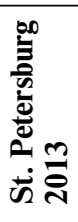 & 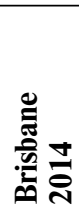 & 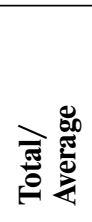 \\
\hline With catalysts & 58 & 56 & 87 & 30 & 65 & 86 & 57 & 82 & 48 & 569 \\
\hline$\%$ & 61.1 & 43.4 & 68.0 & 49.2 & 42.5 & 30.5 & 31.7 & 29.2 & 23.8 & 37.7 \\
\hline Without catalysts & 37 & 73 & 41 & 31 & 88 & 196 & 123 & 199 & 154 & 942 \\
\hline Total & 95 & 129 & 128 & 61 & 153 & 282 & 180 & 281 & 202 & 1,511 \\
\hline
\end{tabular}

The declining trend in the G20 discourse could be explained by the institution's transformation from a crisis response committee to a global governance club with an expanding agenda accommodating a wide range of issues with differing degrees of urgency and thus catalysts. The trend for the BRICS is the opposite, as the group is rapidly institutionalizing and uses newly established mechanisms to facilitate implementing its decisions by issuing mandates to internal institutions and setting timelines.

Table 4: BRICS Commitments with Catalysts

\begin{tabular}{|c|c|c|c|c|c|c|c|}
\hline & 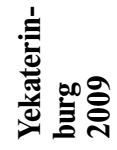 & 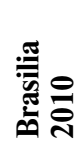 & 营 & 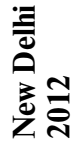 & 产 & 总 & 总 \\
\hline With catalysts & 2 & 8 & 11 & 14 & 25 & 35 & 95 \\
\hline$\%$ & 13.3 & 25.8 & 28.9 & 43.8 & 53.2 & 51.5 & 41.1 \\
\hline Without catalysts & 13 & 23 & 27 & 18 & 22 & 33 & 136 \\
\hline Total & 15 & 31 & 38 & 32 & 47 & 68 & 231 \\
\hline
\end{tabular}


G20 and BRICS commitments use different types of catalysts in ways that reflect their respective nature and features.

Cooperation with international organizations, including the intention to cooperate or statements of support, was embedded in $48.9 \%$ of G20 commitments with catalysts and $69.5 \%$ of BRICS commitments with catalysts. The most frequently mentioned international organizations include the International Monetary Fund (IMF), the Organisation for Economic Cooperation and Development (OECD), the Financial Stability Board, the World Trade Organization (WTO) and the World Bank. The BRICS frequently referred to the United Nations, the IMF and the G20.

The next most frequently used catalyst by the G20 was setting a timeline. Its use varied from summit to summit but the general trend descended from the peak of $62.1 \%$ at the Washington Summit. The BRICS used timelines in only $23.1 \%$ of its commitments with catalysts, with a decreasing trend after the 2009 Yekaterinburg Summit.

The G20 used priority placement more actively (21.8\%) than the BRICS did $(2.1 \%)$. This preference can be explained by the more G20's more complex system of documentation, which typically includes leaders' declarations, action plans and other documentation annexed to the declaration.

The BRICS used internal mandates more frequently (20\%) than the G20 (13.5\%). However, the BRICS issued its first mandate at the 2012 New Delhi Summit, when its institutions had sufficiently evolved, whereas the use of internal mandates is evenly distributed in G20 documents.

The G20 actively used mandates to other institutions (external mandates) from its first summit in Washington, although no new mandates related to implementation were issued at the summits in St. Petersburg and Brisbane. The BRICS issued no external mandates at all, which points to a low level of cooperation with international institutions on implementing BRICS decisions.

Only $6.3 \%$ of G20 commitments and $3.2 \%$ of BRICS commitments contain numerical targets. The G20's London Summit is remarkable because it has largest number of targets (almost $34 \%$ ) in decisions on coordinating fiscal stimulus and strengthening IFI financing. The use of this catalyst later declined, with only $1.8 \%$ in Los Cabos and none in St. Petersburg.

Self-accountability catalysts were more typical for the G20, although they constitute only $2.28 \%$ of all G20 catalysts. The BRICS used these catalysts at New Delhi and Durban with the intention to review progress on the establishing the New Development Bank (NDB) and Contingent Reserve Arrangement (CRA).

Table 5: G20 Catalysts by Type

\begin{tabular}{|c|c|c|c|c|c|c|c|c|c|c|}
\hline & 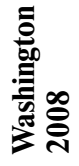 & 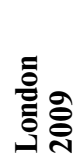 & 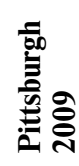 & 흘을 & 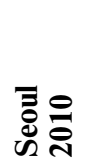 & 䒿 & 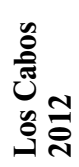 & 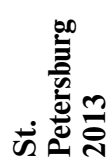 & 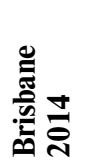 & 苞 \\
\hline $\begin{array}{l}\text { International } \\
\text { organization }\end{array}$ & 18 & 33 & 35 & 20 & 29 & 42 & 24 & 49 & 28 & 278 \\
\hline$\%$ & 31 & 58.9 & 40.2 & 66.7 & 44.6 & 48.8 & 42.1 & 59.8 & 58.3 & 48.9 \\
\hline Timeline & 36 & 15 & 22 & 17 & 16 & 30 & 27 & 12 & 15 & 190 \\
\hline$\%$ & 62.1 & 26.8 & 25.3 & 56.7 & 24.6 & 34.9 & 47.4 & 14.6 & 31.3 & 33.4 \\
\hline
\end{tabular}




\begin{tabular}{|c|c|c|c|c|c|c|c|c|c|c|}
\hline & 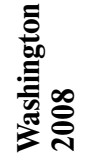 & 产。 & 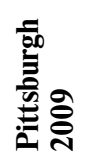 & 홓을 & 言脑 & 总 & 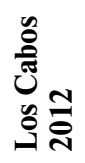 & 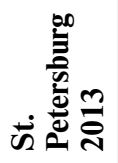 & 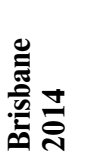 & 唁 \\
\hline $\begin{array}{l}\text { Priority } \\
\text { placement }\end{array}$ & 6 & 11 & 38 & 1 & 25 & 13 & 8 & 16 & 6 & 124 \\
\hline$\%$ & 10.3 & 19.7 & 43.7 & 3.3 & 38.5 & 15.1 & 14 & 19.5 & 12.5 & 21.8 \\
\hline $\begin{array}{l}\text { Internal } \\
\text { mandate }\end{array}$ & 9 & 3 & 15 & 4 & 6 & 8 & 16 & 10 & 6 & 77 \\
\hline$\%$ & 15.5 & 5.4 & 17.2 & 13.3 & 9.2 & 9.3 & 28.1 & 12.2 & 12.5 & 13.5 \\
\hline $\begin{array}{l}\text { External } \\
\text { mandate }\end{array}$ & 9 & 5 & 11 & 9 & 7 & 3 & 2 & 0 & 0 & 46 \\
\hline$\%$ & 15.5 & 8.9 & 12.6 & 30 & 10.8 & 3.5 & 3.5 & 0 & 0 & 8.1 \\
\hline $\begin{array}{l}\text { Numerical } \\
\text { target }\end{array}$ & 0 & 19 & 0 & 0 & 4 & 10 & 1 & 0 & 2 & 36 \\
\hline$\%$ & 0 & 33.9 & 0 & 0 & 6.2 & 11.6 & 1.8 & 0 & 4.2 & 6.3 \\
\hline $\begin{array}{l}\text { Self- } \\
\text { accountability }\end{array}$ & 0 & 1 & 2 & 2 & 0 & 4 & 2 & 2 & 0 & 13 \\
\hline$\%$ & 0 & 1.8 & 2.3 & 6.7 & 0 & 4.7 & 3.5 & 2.4 & 0 & 2.3 \\
\hline
\end{tabular}

Table 6: BRICS Catalysts by Type

\begin{tabular}{|c|c|c|c|c|c|c|c|}
\hline & 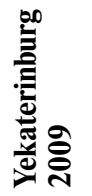 & 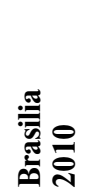 & 窟司 & 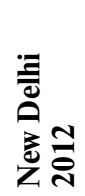 & 产 & 苞 & हैं \\
\hline International organization & 2 & 6 & 7 & 9 & 20 & 22 & 66 \\
\hline$\%$ & 100 & 75 & 63.6 & 64.3 & 80 & 62.9 & 69.5 \\
\hline Internal mandate & 0 & 0 & 0 & 4 & 4 & 11 & 19 \\
\hline$\%$ & 0 & 0 & 0 & 28.6 & 16 & 31.4 & 20 \\
\hline Timeline & 1 & 3 & 4 & 4 & 5 & 5 & 22 \\
\hline$\%$ & 50 & 37.5 & 36.4 & 28.6 & 20 & 14.3 & 23.1 \\
\hline Numerical target & 0 & 0 & 0 & 0 & 2 & 1 & 3 \\
\hline$\%$ & 0 & 0 & 0 & 0 & 8 & 2.9 & 3.2 \\
\hline Self-accountability & 0 & 0 & 0 & 1 & 2 & 0 & 3 \\
\hline$\%$ & 0 & 0 & 0 & 7.1 & 8 & 0 & 3.2 \\
\hline Priority placement & 0 & 0 & 0 & 0 & 1 & 1 & 2 \\
\hline$\%$ & 0 & 0 & 0 & 0 & 4 & 2.9 & 2.1 \\
\hline External mandate & 0 & 0 & 0 & 0 & 0 & 0 & 0 \\
\hline$\%$ & 0 & 0 & 0 & 0 & 0 & 0 & 0 \\
\hline
\end{tabular}

G20 catalysts are unevenly distributed by policy areas. Catalysts are used most frequently for IFI reform (81.4\%), which is to be expected given the need for cooperation to attain results. 
Catalysts are used often in accountability (55.6\%) and international cooperation (45.7\%), and less often in commitments on the core G20 agenda such as trade (39.6\%), financial regulation (34.3\%), macroeconomic policy (25.4\%), and labour and employment (19\%). Thus, the distribution of catalysts depends less on the importance of the policy area than on the possible impact of the international institution on implementation.

Table 7: G20 Catalysts by Issue Area

\begin{tabular}{|c|c|c|c|c|c|c|c|c|c|c|}
\hline & 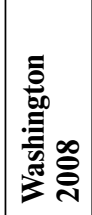 & 总。 & 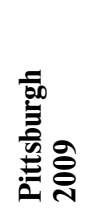 & 产을 & 就是 & 氙 & 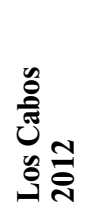 & 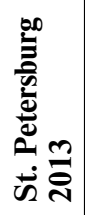 & 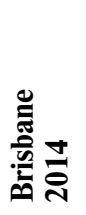 & قै \\
\hline IFI reform & 14 & 29 & 11 & 4 & 16 & 22 & 8 & 5 & 4 & 113 \\
\hline With catalysts & 14 & 23 & 8 & 4 & 14 & 18 & 6 & 3 & 2 & 92 \\
\hline$\%$ & 100 & 79.3 & 72.7 & 100 & 87.5 & 81.8 & 75 & 60 & 50 & 81.4 \\
\hline Climate change & 0 & 3 & 3 & 3 & 8 & 8 & 4 & 11 & 7 & 47 \\
\hline With catalysts & 0 & 1 & 3 & 1 & 3 & 4 & 3 & 6 & 6 & 27 \\
\hline$\%$ & 0 & 33.3 & 100 & 33.3 & 37.5 & 50 & 75 & 54.5 & 85.7 & 57.4 \\
\hline Accountability & 4 & 3 & 15 & 2 & 4 & 5 & 13 & 9 & 17 & 72 \\
\hline With catalysts & 2 & 3 & 15 & 1 & 1 & 2 & 10 & 2 & 4 & 40 \\
\hline$\%$ & 50 & 100 & 100 & 50 & 25 & 40 & 76.9 & 22.2 & 23.5 & 55.6 \\
\hline $\begin{array}{l}\text { Crime and } \\
\text { corruption }\end{array}$ & 3 & 0 & 3 & 3 & 8 & 5 & 7 & 34 & 4 & 67 \\
\hline With catalysts & 1 & 0 & 2 & 3 & 2 & 5 & 3 & 16 & 0 & 32 \\
\hline$\%$ & 0 & 0 & 66.7 & 100 & 25 & 100 & 42.9 & 47.1 & 0 & 47.8 \\
\hline $\begin{array}{l}\text { International } \\
\text { cooperation }\end{array}$ & 0 & 0 & 4 & 0 & 2 & 12 & 5 & 12 & 0 & 35 \\
\hline With catalysts & 0 & 0 & 4 & 0 & 0 & 4 & 2 & 6 & 0 & 16 \\
\hline$\%$ & 0 & 0 & 100 & 0 & 0 & 0 & 40 & 0 & 0 & 45.7 \\
\hline Energy & 0 & 0 & 16 & 1 & 14 & 18 & 10 & 19 & 16 & 94 \\
\hline With catalysts & 0 & 0 & 10 & 1 & 6 & 7 & 2 & 10 & 3 & 39 \\
\hline$\%$ & 0 & 0 & 62.5 & 100 & 42.9 & 38.9 & 20 & 52.6 & 18.8 & 41.5 \\
\hline Trade & 5 & 14 & 6 & 9 & 17 & 15 & 9 & 12 & 9 & 96 \\
\hline With catalysts & 4 & 4 & 4 & 6 & 5 & 6 & 2 & 4 & 3 & 38 \\
\hline$\%$ & 80 & 28.6 & 66.7 & 66.7 & 29.4 & 40 & 22.2 & 33.3 & 33.3 & 39.6 \\
\hline Development & 4 & 15 & 9 & 8 & 22 & 17 & 10 & 50 & 11 & 146 \\
\hline With catalysts & 2 & 9 & 6 & 4 & 9 & 2 & 2 & 16 & 2 & 52 \\
\hline$\%$ & 50 & 60 & 66.7 & 50 & 40.9 & 11.8 & 20 & 32 & 18.2 & 35.6 \\
\hline $\begin{array}{l}\text { Financial } \\
\text { regulation }\end{array}$ & 59 & 45 & 23 & 12 & 24 & 38 & 18 & 21 & 11 & 251 \\
\hline With catalysts & 29 & 5 & 10 & 7 & 8 & 8 & 11 & 4 & 4 & 86 \\
\hline
\end{tabular}




\begin{tabular}{|c|c|c|c|c|c|c|c|c|c|c|}
\hline & 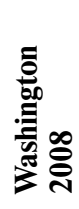 & 茟。言 & 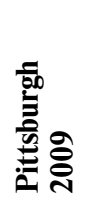 & 总。 & 总禺 & 总 & 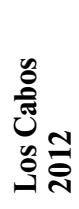 & 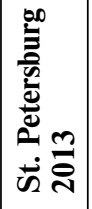 & 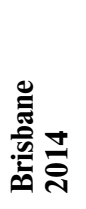 & हैं \\
\hline$\%$ & 49.2 & 11.1 & 43.5 & 58.3 & 33.3 & 21.1 & 61.1 & 19.0 & 36.4 & 34.3 \\
\hline $\begin{array}{l}\text { Socioeconomic } \\
\text { policy }\end{array}$ & 0 & 1 & 1 & 2 & 6 & 2 & 3 & 0 & 0 & 15 \\
\hline With catalysts & 0 & 1 & 1 & 1 & 0 & 2 & 0 & 0 & 0 & 5 \\
\hline$\%$ & 0 & 100 & 100 & 50 & 0 & 100 & 0 & 0 & 0 & 33.3 \\
\hline $\begin{array}{l}\text { Food and } \\
\text { agriculture }\end{array}$ & 0 & 0 & 3 & 2 & 2 & 36 & 4 & 11 & 0 & 58 \\
\hline With catalysts & 0 & 0 & 3 & 0 & 1 & 9 & 2 & 2 & 0 & 17 \\
\hline$\%$ & 0 & 0 & 100 & 0 & 50 & 25 & 50 & \begin{tabular}{|l|}
18.2 \\
\end{tabular} & 0 & 29.3 \\
\hline $\begin{array}{l}\text { Macroeconomic } \\
\text { policy }\end{array}$ & 6 & 15 & 28 & 15 & 28 & 91 & 67 & 67 & 41 & 358 \\
\hline With catalysts & 6 & 9 & 19 & 2 & 16 & 17 & 12 & 6 & 4 & 91 \\
\hline$\%$ & 100 & 60 & 67.9 & 13.3 & 57.1 & 18.7 & 17.9 & 9 & 9.8 & 25.4 \\
\hline $\begin{array}{l}\text { Labour and } \\
\text { employment }\end{array}$ & 0 & 4 & 6 & 0 & 0 & 8 & 18 & 29 & 18 & 84 \\
\hline With catalysts & 0 & 1 & 2 & 0 & 0 & 2 & 1 & 6 & 4 & 16 \\
\hline$\%$ & 0 & 25 & 33.3 & 0.0 & 0 & 25.0 & 5.6 & \begin{tabular}{|l|}
20.7 \\
\end{tabular} & 22.2 & 19 \\
\hline
\end{tabular}

Note: IFI $=$ international financial institution.

Because there is a relatively low number of BRICS commitments with catalysts, it is not possible to analyze the distribution by policy areas. Catalysts were most frequently used on IFI reform $(87.5 \%)$, terrorism $(66.7 \%)$, climate change $(58.3 \%)$, development $(56.5 \%)$, international cooperation (56\%) and regional security (40\%). However, the trend across summits is quite mixed.

In conclusion, the evolving institutionality of the BRICS was accompanied by a rise in the use of commitment catalysts, which mostly included references to international institutions, internal mandates and timelines. The same three types of catalysts were prioritized in G20 documents, although the G20's use of commitment catalysts declined.

\section{Compliance Catalysts: How They Work or Do Not Work}

Two subsets of commitments with and without embedded catalysts were compared to assess whether commitment catalysts affect compliance performance.

Compliance assessments are available for 114 G20 commitments made from 2008 to 2014 (see Table 8). The number of monitored commitments increased steadily, with only three analyzed in the 2008 Washington Summit compliance report and 16 to 17 commitments assessed for each summit after Cannes in 2011 to Brisbane in 2014.

Catalysts were built into all three commitments assessed for Washington. For London, the number of commitments with catalysts included in the compliance assessment dropped to two. Eight of nine Pittsburgh commitments monitored contained catalysts. After the Toronto Sum- 
mit, the number of monitored commitments with catalysts remained relatively stable at about $30 \%$ of all commitments assessed.

Table 8: G20 Commitments, Compliance Assessments and Monitored Commitments with Catalysts, 2008-2014

\begin{tabular}{|c|c|c|c|c|c|c|c|c|c|c|}
\hline Summit & 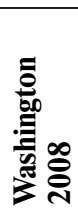 & 产。 & 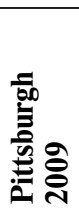 & 을 을 & 言㐫 & 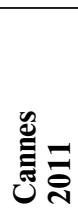 & 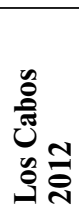 & 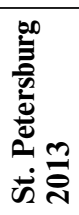 & 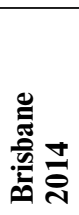 & 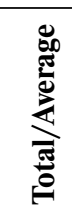 \\
\hline Commitments & 95 & 129 & 128 & 61 & 153 & 282 & 180 & 281 & 202 & 1,511 \\
\hline Monitored commitments & 3 & 13 & 9 & 10 & 13 & 16 & 17 & 16 & 17 & 114 \\
\hline $\begin{array}{l}\text { Monitored commitments } \\
\text { with catalysts }\end{array}$ & 3 & 2 & 8 & 5 & 5 & 5 & 4 & 6 & 5 & 43 \\
\hline$\%$ & 100 & 15.4 & 88.9 & 50 & 38.5 & 31.3 & 23.5 & 37.5 & 29.4 & 37.7 \\
\hline
\end{tabular}

For the BRICS, of the 23 commitments assessed in the compliance reports from 2009 to 2014, 10 contained catalysts (see Table 9). Only one of the five commitments monitored for the Sanya Summit had embedded catalysts. Between 2012 and 2014, about a half the monitored commitments included catalysts.

Table 9: BRICS Commitments, Compliance Assessments and Monitored Commitments with Catalysts, 2009-2014

\begin{tabular}{|c|c|c|c|c|c|c|c|}
\hline Summit & 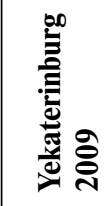 & 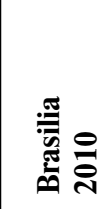 & 尝 & 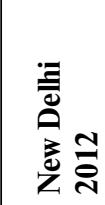 & 言 & 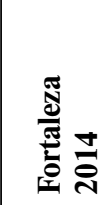 & 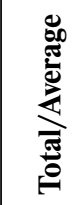 \\
\hline Commitments & 15 & 31 & 38 & 32 & 47 & 68 & 231 \\
\hline Monitored commitments & 0 & 0 & 5 & 5 & 5 & 8 & 23 \\
\hline Monitored commitments with catalysts & 0 & 0 & 1 & 3 & 2 & 4 & 10 \\
\hline$\%$ & $\mathrm{n} / \mathrm{a}$ & $\mathrm{n} / \mathrm{a}$ & 20 & 60 & 40 & 50 & 43.48 \\
\hline
\end{tabular}

Note: $\mathrm{n} / \mathrm{a}=$ not applicable

A comparison of the commitments with and without embedded catalysts reveals that the average compliance score for those with catalysts was lower than those without catalysts for six out the eight G20 summits assessed (see Table 10). Commitments with catalysts registered slightly higher compliance scores only in Toronto and Cannes. The gap between commitments with and without catalysts widened after the Los Cabos Summit. As a result, the average compliance score for commitments with catalysts amounted to +0.31 , the average for all commitments was +0.43 and the average for commitments without catalysts was +0.49 . 
Table 10: G20 Compliance Assessments, 2008-2014

\begin{tabular}{|c|c|c|c|c|c|c|c|c|c|c|}
\hline Summit & 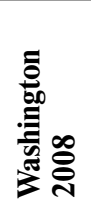 & 总。 & 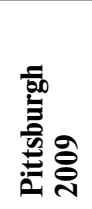 & 产电 & 言恼 & 氖 & 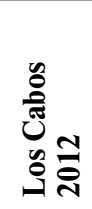 & 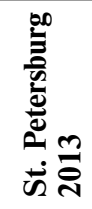 & 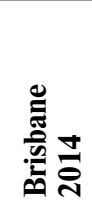 & 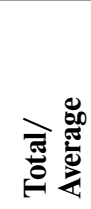 \\
\hline Monitored commitments & 3 & 13 & 9 & 10 & 13 & 16 & 17 & 16 & 17 & 114 \\
\hline Average score & +0.59 & +0.34 & +0.22 & +0.38 & +0.5 & +0.55 & +0.57 & +0.44 & +0.25 & +0.43 \\
\hline $\begin{array}{l}\text { Monitored commitments } \\
\text { with catalysts }\end{array}$ & 3 & 2 & 8 & 5 & 5 & 5 & 4 & 6 & 5 & 43 \\
\hline Average score & +0.59 & +0.25 & +0.16 & +0.39 & +0.45 & +0.57 & +0.43 & +0.04 & -0.11 & +0.31 \\
\hline $\begin{array}{l}\text { Monitored commitments } \\
\text { without catalysts }\end{array}$ & 0 & 11 & 1 & 5 & 8 & 11 & 13 & 10 & 12 & 71 \\
\hline Average score & $\mathrm{n} / \mathrm{a}$ & +0.36 & +0.38 & +0.37 & +0.57 & +0.54 & +0.62 & +0.68 & +0.40 & +0.49 \\
\hline
\end{tabular}

Note: $\mathrm{n} / \mathrm{a}=$ not applicable

The trend is similar for the BRICS (see Table 11). The average compliance score on commitments with catalysts was +0.40 , which is slightly lower than the average compliance for all commitments $(+0.41)$ and for commitments without catalysts $(+0.46)$. The score for commitments with catalysts was higher than the figure for the other commitments at the Sanya and Durban summits, but substantially lower for New Delhi and Fortaleza.

Table 11: BRICS Compliance Assessments, 2011-2014

\begin{tabular}{|c|c|c|c|c|c|}
\hline Summit & 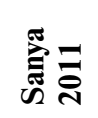 & 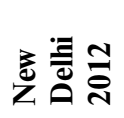 & 言 & 它 芯 & है \\
\hline Monitored commitments & 5 & 5 & 5 & 8 & 23 \\
\hline Average score & +0.48 & +0.28 & +0.48 & +0.40 & +0.41 \\
\hline Monitored commitments with catalysts & 1 & 3 & 2 & 4 & 10 \\
\hline Average score & +0.60 & +0.20 & +0.50 & +0.30 & +0.40 \\
\hline Monitored commitments without catalysts & 4 & 2 & 3 & 4 & 13 \\
\hline Average score & +0.45 & +0.40 & +0.47 & +0.50 & +0.46 \\
\hline
\end{tabular}

According to a comparison of the G20's compliance scores for commitments with and without catalysts, catalysts encouraged compliance on only the three issue areas of trade, food and agriculture, and international cooperation (see Table 12). In the other seven issue areas for which scores were available for both subsets of commitments, the G20 generally performed better on commitments without catalysts. Average compliance performance on issue areas where all commitments assessed do not contain catalysts (health and infrastructure) was relatively high $(+0.58$ and +0.65 , respectively). Compliance scores on crime and corruption and on IFI reform, with catalysts in all monitored commitments, lag behind (at +0.12 and +0.48 , respectively). 
Table 12: G20 Compliance Performance by Issue Area, 2008-2014

\begin{tabular}{|c|c|c|c|c|c|c|c|c|c|c|}
\hline & 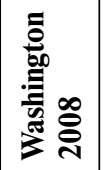 & 产 & 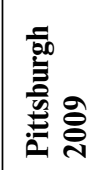 & 을 을 & 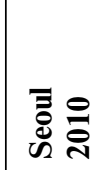 & 总 & 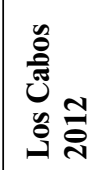 & 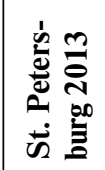 & 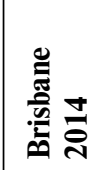 & 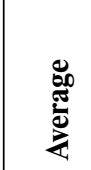 \\
\hline \multicolumn{11}{|l|}{ Without catalysts } \\
\hline Trade & & +0.50 & & & -0.05 & & +0.25 & & +0.05 & +0.19 \\
\hline Development & & +0.30 & & +0.15 & +0.60 & +0.33 & +0.78 & +0.38 & +0.13 & +0.38 \\
\hline Macroeconomic policy & & +0.43 & & +0.73 & +0.89 & +0.44 & +0.68 & +0.70 & +0.05 & +0.56 \\
\hline Financial regulation & & 0 & & +0.10 & +0.67 & +0.57 & +0.15 & & +0.30 & +0.30 \\
\hline Energy & & & +0.75 & & +0.80 & +0.95 & & & +0.85 & +0.84 \\
\hline Labour and employment & & & & & & +0.70 & +1.00 & +0.85 & +0.45 & +0.75 \\
\hline International cooperation & & & & & +0.05 & & & & & +0.05 \\
\hline Climate change & & & & & & & +0.70 & & & +0.70 \\
\hline Food and agriculture & & & & +0.15 & & & +0.35 & +0.80 & & +0.43 \\
\hline Socioeconomic policy & & & & & +0.90 & & +0.55 & & & +0.73 \\
\hline Health & & & & & & & & & +0.58 & +0.58 \\
\hline Infrastructure & & & & & & & & & +0.65 & +0.65 \\
\hline \multicolumn{11}{|l|}{ With catalysts } \\
\hline Trade & +0.59 & +0.50 & +0.10 & +0.15 & & +0.50 & & -0.35 & & +0.25 \\
\hline Development & & & -0.05 & & & & & -0.25 & & -0.15 \\
\hline Macroeconomic policies & & & +0.70 & +0.67 & +0.25 & & & & -0.05 & +0.39 \\
\hline Financial regulation & & & +0.15 & & +0.60 & & +0.61 & +0.35 & -0.25 & +0.29 \\
\hline Energy & & & & +0.45 & +0.37 & +0.63 & +0.58 & +0.55 & -0.35 & +0.37 \\
\hline Labour and employment & & & & & & & & & +0.11 & +0.11 \\
\hline International cooperation & & & & & & +0.25 & & & & +0.25 \\
\hline Climate change & & & & & & & & -0.20 & 0 & -0.10 \\
\hline Food and agriculture & & & & & & +0.95 & & & & +0.95 \\
\hline Socioeconomic policy & & 0 & & & & & & & & 0 \\
\hline Crime and corruption & & & +0.30 & -0.20 & +0.45 & & -0.10 & +0.15 & & +0.12 \\
\hline IFI reform & & & +0.05 & +0.90 & & +0.50 & & & & +0.48 \\
\hline
\end{tabular}

Note: IFI $=$ international financial institution.

The BRICS complied equally well on commitments with and without catalysts in the areas of development and IFI reform (see Table 13). On trade, commitments without catalysts received a higher compliance score $(+0.40)$ than those with catalysts $(0)$. However, as the data on 
BRICS compliance are limited to four summits, further research is needed to make convincing conclusions on BRICS comparative performance across the two subsets.

Table 13: BRICS Compliance Performance by Issue Areas, 2011-2014

\begin{tabular}{|l|c|c|}
\hline & With catalysts & Without catalysts \\
\hline Development & +0.60 & +0.60 \\
\hline Reform of international financial institutions & +0.20 & +0.20 \\
\hline Trade & 0 & +0.40 \\
\hline Crime and corruption & +0.80 & \\
\hline Terrorism & +0.50 & +1.00 \\
\hline Environment & & +0.60 \\
\hline Energy & & +0.60 \\
\hline Health & & +0.50 \\
\hline Climate change & & +0.30 \\
\hline Financial regulation & & +0.20 \\
\hline Macroeconomic policies & & +0.20 \\
\hline Regional security & & \\
\hline
\end{tabular}

In summary, on average G20 and BRICS compliance performance was higher on commitments without catalysts than on those with catalysts. This finding applied to both the comparison across summits and across issue areas. Thus, catalysts on compliance performance had a mainly negative impact on the G20 and the BRICS.

However, the degree and direction of this influence depended on the type of catalyst. The G20 generally demonstrated good performance on commitments containing self-accountability pledges (with an average score of +0.55 for this set of commitments, compared to the overall average of +0.45 ) (see Table 14). Commitments with timelines also registered relatively high compliance scores, with the average of +0.34 (however, it is lower than the overall average score for the institution). By contrast, results for commitments with numerical targets were negative, with an average of -0.07 . Ambitious numerical targets are evidently harder to comply with and can take some time to be achieved, while compliance cycle (from summit to summit) is relatively short.

Compliance scores on commitments with priority placements and mandates were also lower than the overall G20 average. With an average score of +0.28 , engagement with international organizations cited in the G20 commitments failed to contribute much to compliance.

Although BRICS compliance scores are only available for ten commitments with catalysts, comparison of the findings leads to the same conclusions as for the G20 (see Table 15). The effect of timelines seems positive (it should be noted, however, that the score of +0.80 represents a single assessed commitment to accelerate attaining the education-related Millennium Development Goals by 2015). BRICS compliance on commitments that reflect engagement with international organizations was +0.29 , almost equal to the $G 20$ score and lower than the BRICS overall score of +0.41 . 
Table 14: G20 Compliance on Commitments by Catalyst Type

\begin{tabular}{|l|c|c|c|}
\hline \multicolumn{1}{|c|}{ Catalyst type } & $\begin{array}{c}\text { Number } \\
\text { of commitments }\end{array}$ & $\begin{array}{c}\text { Number } \\
\text { of commitments assessed }\end{array}$ & $\begin{array}{c}\text { Compliance } \\
\text { score }\end{array}$ \\
\hline Priority placement & 124 & 10 & +0.21 \\
\hline Numerical target & 36 & 2 & -0.07 \\
\hline Timeline & 190 & 16 & +0.34 \\
\hline Self-accountability mechanisms & 13 & 3 & +0.55 \\
\hline External mandate & 46 & 1 & $\mathrm{n} / \mathrm{a}$ \\
\hline Internal mandate & 77 & 18 & +0.25 \\
\hline $\begin{array}{l}\text { Engagement with international } \\
\text { organizations }\end{array}$ & 278 & & +0.28 \\
\hline
\end{tabular}

Note: $\mathrm{n} / \mathrm{a}=$ not applicable

Table 15: BRICS Compliance on Commitments by Catalyst Type

\begin{tabular}{|l|c|c|c|}
\hline \multicolumn{1}{|c|}{ Catalyst type } & $\begin{array}{c}\text { Number of } \\
\text { commitments }\end{array}$ & $\begin{array}{c}\text { Number of commitments } \\
\text { assessed }\end{array}$ & $\begin{array}{c}\text { Compliance } \\
\text { score }\end{array}$ \\
\hline Priority placement & 2 & 0 & $\mathrm{n} / \mathrm{a}$ \\
\hline Numerical target & 3 & 0 & $\mathrm{n} / \mathrm{a}$ \\
\hline Timeline & 17 & 1 & +0.80 \\
\hline Self-accountability mechanisms & 3 & 0 & $\mathrm{n} / \mathrm{a}$ \\
\hline External mandate & 0 & 0 & $\mathrm{n} / \mathrm{a}$ \\
\hline Internal mandate & 19 & 0 & $\mathrm{n} / \mathrm{a}$ \\
\hline $\begin{array}{l}\text { Engagement with international } \\
\text { organizations }\end{array}$ & 66 & 9 & +0.29 \\
\hline
\end{tabular}

Note: $\mathrm{n} / \mathrm{a}=$ not applicable

Thus, the study reveals that catalysts built into commitments affect G20 and BRICS compliance performance, although in most cases the impact is negative. The degree of influence according to type of catalyst has also turned out to be valid. Self-accountability pledges and timelines embedded in commitments tend to influence performance positively (or at least neutrally), whereas compliance on commitments with other types of catalysts is lower than average. This is true for engagement with international organizations. Thus, the findings do not confirm the hypothesis that G20 and BRICS compliance would increase if the institutions engage with international organizations in a governing-in-alliance or a governing-through mode.

Further research is needed, however, given the limitations of the existing database. Future compliance studies may generate new data with more attention given to a balanced representation of commitments with and without catalysts. Future monitoring studies might also take into account the fact that commitments with catalysts, especially numerical targets, are assessed according to very rigorous scoring guidelines, reflecting their ambitious nature. This is not to say that the rigour should be relaxed but that there should be an awareness of the contradiction 
between the ambitious and long-term nature of commitments and the relatively short assessment period in designing the methodology.

\section{External Causes of Compliance: Empowering Implementation}

Two clear trends emerge in the study of G20 and BRICS discourse: the proportion of commitments responding to demand for G20 collective action to resolve urgent challenges (priority) declines, while the number of self-accountability commitments related to G20 performance rises (see Figure 3). The demand for the BRICS actions in also generally falling with a slight spike observed at New Delhi and Durban, whereas the self-accountability mechanisms are nascent. For both the G20 and the BRICS the average compliance with priority commitments is higher than the average for the rest of the sample.

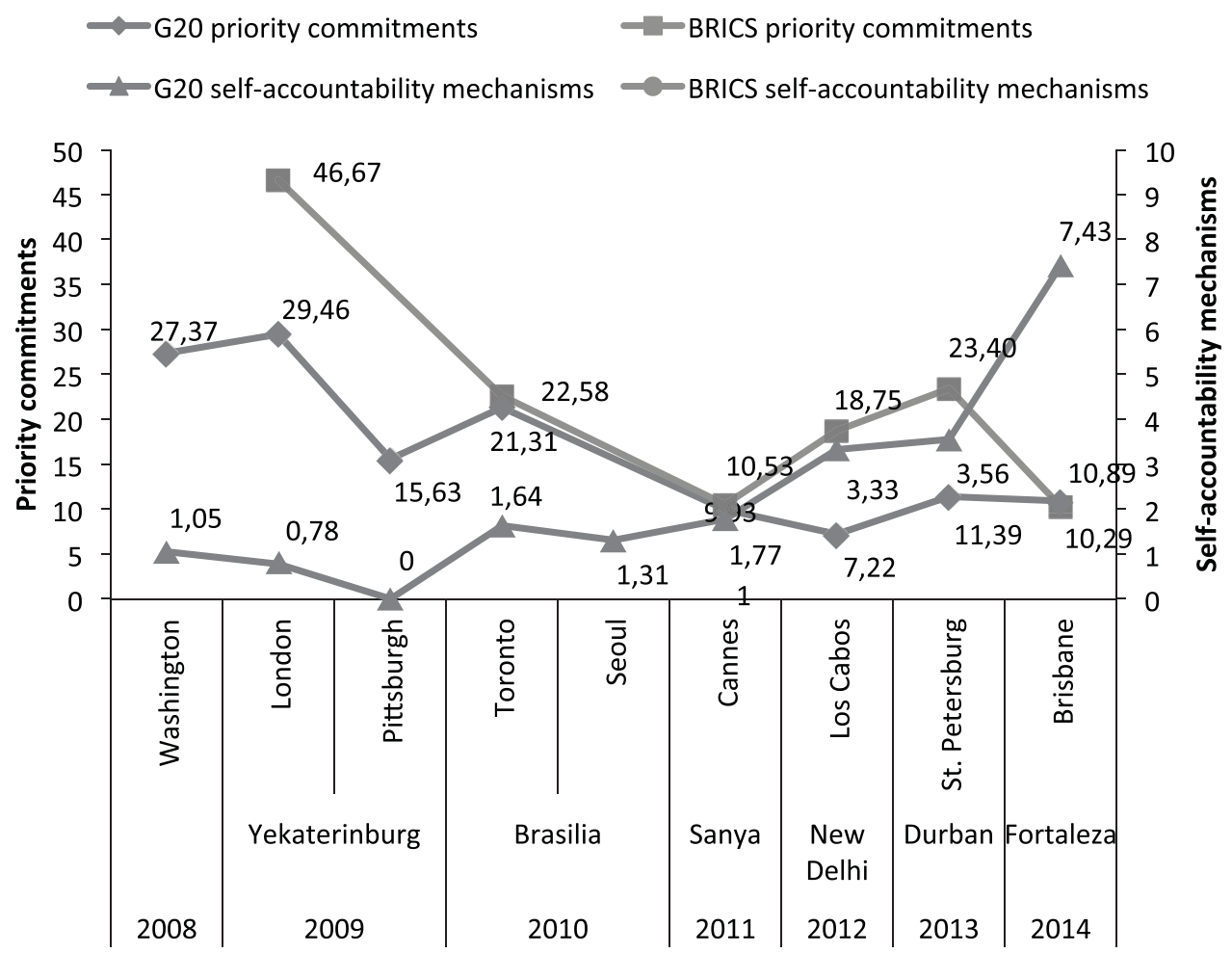

Figure 3: G20 and BRICS Priority and Self-Accountability Commitments, 2008-2014

Washington and London had the highest share of priority commitments with $27.4 \%$ and $29.5 \%$ of the total respectively. At Washington the leaders pledged to restore growth, ensure closer macroeconomic cooperation, stabilize the financial system, strengthen the transparency and efficiency of financial markets, work together to enhance regulatory cooperation among jurisdictions, refrain from raising new barriers to trade and investment, advance the reform of the Bretton Woods institutions, and ensure that the IMF, World Bank and other multilateral development banks have sufficient resources to help overcome the crisis. Since Washington both commitment catalysts and self-accountability commitments have been present in the G20 
discourse. The most frequently used type of catalyst was the timeline. However, of the total 95 pledges only one was a self-accountability commitment: given the prominence of reforming the financial system on the G20 agenda, the leaders agreed to meet again to review implementation by 30 April 2009. The main compliance catalyst for the Washington commitments was a shared sense of the need for collective and coordinated action, as confirmed by compliance performance with the pledge to reject protectionism reaching +0.59 , a success in the area not yet repeated in the history of G20 since then.

The London Summit resulted in the leaders' agreement to triple the IMF resources to $\$ 750$ billion; support a new allocation of $\$ 250$ billion for special drawing rights, $\$ 100$ billion in additional lending by the multilateral development banks, $\$ 250$ billion for trade finance and IMF gold sales for concessional finance for the poorest countries; and undertake a concerted fiscal expansion amounting to $\$ 5$ trillion to save jobs and raise output by $4 \%$. They also agreed to establish the new Financial Stability Board as a successor to the Financial Stability Forum and implement the package of IMF quota and voice reforms agreed in April 2008 and the World Bank reforms agreed in October 2008. Many of the 129 commitments were reinforced by numerical targets and timelines. One self-accountability commitment contained the decision "to meet again before the end of this year to review progress on our commitments" [G20, 2009].

Even though the urgency for collective action was acutely felt in March 2009, the average compliance performance with the London commitments was low. Two factors explain this outcome. One factor was the multitude of numerical targets, which was a unique feature of the London commitments, made them harder to comply with. The other factor was the compliance period between the London and Pittsburgh summits was too short to allow for the full range of necessary actions. A good example is the commitment to reshape the regulatory systems so that authorities can identify and assess macroprudential risks, which received a score of 0 as a work in progress. Despite these factors, compliance performance with the priority commitments $(+0.37)$ was significantly higher than compliance with the rest of the sample for London $(+0.28)$. This is characteristic of G20 compliance for the period as the club average compliance with priority commitments was +0.49 compared to +0.40 on other commitments. The outlier was G20 performance on Pittsburgh decisions.

The G20's failure to comply with the Pittsburgh priority commitments ( +0.04 compared to +0.37 for the other commitments) marks a drop in the members' performance on their pledge to refrain from raising barriers to investment and trade in goods and services, as well as imposing new export restrictions or implementing WTO-inconsistent measures to stimulate exports and rectify such measures as they arise. With an average of +0.10 for Pittsburgh, the G20 did not return to the level it sustained for Washington $(+0.59)$ and London $(+0.50)$. The commitment to shift at least $5 \%$ of the IMF quota share of overrepresented countries to dynamic emerging markets and developing countries proved a challenge that the G20 was not able to resolve even seven summits later. Only two of 128 Pittsburgh commitments were reinforced by self-accountability catalysts: the decision to rationalize and phase out inefficient fossil fuel subsidies, which encourage wasteful consumption, over the medium term and the promise to facilitate the conclusion of the WTO's Doha Development Round and trade facilitation agreement. Moreover, Pittsburgh was the only summit that made no self-accountability commitments. The lowest compliance in G20 history can be explained by a combination of a diminishing sense of urgency, a wide range of challenging commitments and a lack of self-accountability mechanisms.

At the Toronto Summit, for the first time the G20 leaders expressed their determination to be accountable for the commitments they made, and instructed their ministers and officials to take all necessary steps to implement them fully within agreed timelines. Nonetheless, compliance performance was only slightly higher than for Pittsburgh. However, delivery on priority 
commitments $(+0.50)$ was much higher than the average for the other commitments $(+0.33)$, with two exceptions: the commitment to avoid protectionism and the promise to implement country-specific strategies to rationalize and phase out inefficient fossil fuel subsidies over the medium term. The Toronto Summit was the first held in the G20's new capacity as the premier forum for its members' international economic cooperation, and the leaders were gravely aware that to sustain recovery, they needed to follow through on their macroeconomic policy decisions on fiscal stimulus and "growth friendly" fiscal consolidation plans in advanced countries and on structural reforms across the entire G20 membership. This new impetus for continued cooperation to strengthen the recovery and lay the foundation for strong, sustainable and balanced growth encouraged implementation with the priority commitments.

The Seoul Summit, remarkable for the Seoul Development Consensus and Multi-Year Action Plan on Development as well as the focus on the structural reforms, consolidated the self-accountability dimension of G20 cooperation as the leaders reaffirmed that the G20 would hold itself accountable for its commitments. A significant rise in the average compliance performance for Seoul commitments $(+0.50)$ came as the result of the combination of the members' resolution to implement collective and individual commitments to advance strong, sustainable and balance growth stated in the action plan and burgeoning self-accountability mechanisms responding to peer pressure and demand for G20 effectiveness from external stakeholders. The leaders promised: "We will continue to monitor and assess ongoing implementation of the commitments made today and in the past in a transparent and objective way. We hold ourselves accountable. What we promise, we will deliver" [G20, 2010a]. Performance on the priority commitments was contradictory. On the one hand, the G20 resolution to implement structural reforms to boost and sustain global demand, foster job creation, contribute to global rebalancing, and increase growth potential was confirmed by very high compliance on the commitment to address bottlenecks and enhance growth potential through investment in infrastructure $(+0.90)$. On the other hand, the G20 again failed to deliver on the anti-protectionist standstill commitments $(-0.05)$. The increase in delivery rested on a shared sense of urgency and peer pressure.

At the Cannes Summit, the G20 focused on providing more and better jobs as the ultimate objective of the action plan to address short-term vulnerabilities and strengthen medium-term foundations for growth. The G20 also further consolidated its self-accountability mechanisms. Members agreed to enhance reporting and monitoring in 2012 and in future years, developing a framework to assess progress on the commitments for reforming fiscal, financial, structural, monetary, exchange rate, trade and development policies. The average compliance performance for Cannes reaching +0.55 with an average of +0.49 for the priority commitments. However, the G20 delivered well on several key priority commitments; the promise to renew efforts to combat unemployment and promote decent jobs, especially for youth and others most affected by the economic crisis, was implemented by most members and scored +0.7 . The G20's relatively high performance $(+0.5)$ with the commitment to refrain from protectionism and to roll back any new protectionist measures - traditionally hard to comply with - is an example of how persistent demand for action and accountability mechanisms can act together to catalyze compliance.

Under the Mexican presidency, the G20 put employment at the heart of its macroeconomic policies, fully complying with the commitment to combat unemployment through appropriate labour market measures and foster the creation of decent work and quality jobs. G20 members reported on their progress on their individual policy commitments and adopted an accountability assessment framework [G20, 2012a, b]. They also promised to review progress against all of the commitments at their next summit in St. Petersburg, thus further consolidat- 
ing the peer pressure and transparency mechanisms. The 180 Los Cabos commitments were reinforced by eight self-accountability pledges. The average level of compliance $(+0.57)$ was the highest since Washington, with the average for priority commitments reaching +0.61 .

The St. Petersburg Summit resulted in 281 commitments, second only to Cannes. In their declaration and the action plan, the leaders agreed to improve domestic and international investment conditions, improve the business environment, implement pro-growth structural reforms in product and labour markets, and develop comprehensive growth strategies and country-specific plans on employment. The growth strategies and employment plans were developed and adopted at the Brisbane Summit the following year. The G20 emphasized encouraging the private sector, including small and medium-sized enterprises as one of the most important partners, in fostering inclusive economic growth for job creation. The commitment to improve the business environment was fully implemented by all members. The average level of compliance with the priority commitments at +0.58 was much higher than for the rest of the sample (+0.36). Two exceptions should be noted here. One was the modest delivery on the promise to tackle tax avoidance, harmful practices and aggressive tax planning, which, at +0.35 , was lower than expected given the prominence of the issue on the St. Petersburg agenda and the priority of improving the business environment and building inclusive societies. The other exception was the pledge to extend the standstill commitment until the end of 2016, so the regularly low performance to resist protectionism dropped to -0.35 , the lowest to date. The ten self-accountability commitments with timelines were intended to advance progress on a wide range of G20 decisions.

The key takeaways from the Brisbane Summit included the commitment that the members' employment plans should work alongside their comprehensive growth strategies to integrate macroeconomic and labour market policies more effectively. The leaders agreed to lift the G20's gross domestic product (GDP) by at least an additional $2 \%$ by 2018. Mindful of the global impact of their collective actions, G20 leaders promised that their decisions would boost non-G20 GDP by more than $0.5 \%$ by 2018 . Through the Global Infrastructure Initiative, endorsed at the summit, the G20 aimed to increase quality public and private infrastructure investment and agreed to establish the Global Infrastructure Hub with a four-year mandate to support the implementation of the initiative. For the first time in the G20's history the leaders not only expressed disappointment with the continued delay in the IMF quota and governance reforms agreed in 2010 and the 15th General Review of Quotas, including a new quota formula, but also asked the IMF to stand ready with options for next steps, if the United Stated failed to ratify the reforms by the end of the year. The leaders promised to hold each other to account for implementing their commitments and to review progress at their next meeting. The $15 \mathrm{ac}-$ countability commitments were intended to reinforce compliance and ultimately enhance G20 effectiveness. Self-accountability commitments present in the G20 since the first summit in Washington were transformed into a full-fledged and comprehensive mechanism.

Turkey's G20 presidency in 2015 listed its core priorities as investment for growth, inclusive development and implementation of commitments. At the Antalya Summit, the leaders reiterated their Brisbane pledge to increase their collective GDP by an additional 2\% by 2018 through growth strategies adjusted in response to evolving economic conditions and ambitious countryspecific investment strategies. G20 members agreed to monitor implementation closely through the robust framework developed with support of the OECD, IMF and the World Bank. The leaders made 113 commitments, 13 of which were in the Statement on the Fight Against Terrorism adopted in the aftermath of the terrorist attacks in Paris on 13 November on the eve of the summit. The leaders reiterated their resolve to work together to prevent and suppress terrorist acts through increased international solidarity and cooperation, in full recognition of the UN's 
central role and in accordance with the UN Charter and obligations under international law. The accountability commitments were intended for monitoring the implementation of growth strategies and employment plans and progress on resisting protectionist measures. At the time of writing compliance data on Antalya commitments was still being analyzed, but it can be assumed that the shared sense of urgency for collective actions and the accountability framework will likely encourage compliance performance.

Thus the main compliance catalysts for Washington and London were the shared sense of urgency for collective and coordinated actions. In spite of the Pittsburgh breakthroughs on the Framework for Strong, Sustainable and Balanced Growth and the establishment of the G20 as a premier forum for its members' economic cooperation, compliance was the lowest in G20 history, which may be explained by the summit fatigue, abating sense of urgency for the collective actions, and absence of self-accountability pledges. From Toronto onward the G20 shaped and consolidated self-accountability mechanisms. An increase in the compliance performance for Toronto resulted from a combined effect of two factors: responding to demand for coordinated actions and enhancing self-accountability. Although the compliance performance on the Seoul and Cannes priority commitments was lower than for the other commitments, the upward trend in average performance remained steady, reflecting the institution's increasing capability of delivery reinforced by self-accountability mechanisms. Los Cabos continued the trend and demonstrated higher compliance performance with the priority commitments. The average level of compliance with the St. Petersburg commitments dropped slightly, but the average for priority commitments was second only to Los Cabos and Cannes.

To sum up, the G20's shared sense of urgency and systemic self-accountability encouraged implementation. These two factors do not have a linear or universal effect, but they may complement and reinforce each other. As the G20 becomes increasingly institutionalized, implementation becomes a value, if not a norm, with self-accountability acting as a safeguard for delivery.

The decline in priority commitments is also characteristic for the BRICS, with its share amounting to $46.7 \%$ in Yekaterinburg (2009), where the leaders committed to advance IFI reform, support the diversification of energy resources and supply, and contribute to the efforts to overcome the global food crisis. The proportion of priority commitments fell to $22.6 \%$ in Brasilia (2010) and 10.5\% in Sanya (2010). At both summits, the BRIC leaders emphasized their commitment to resist protectionism, promote the reform of the Bretton Woods institutions, and develop cleaner, more affordable and sustainable energy systems (South Africa was not yet a member). At Sanya they agreed to support infrastructure development in Africa and its industrialization within the framework of the New Partnership for Africa's Development (NEPAD). Sanya's average compliance score was +0.48 , higher than average for the period under study. At Sanya the leaders made their first and only self-accountability commitment, pledging to review the implementation of their action plan at their next meeting.

The downward trend in priority commitments was reversed at New Delhi (2012) and Durban (2013) with the decisions to establish the NDB for mobilizing resources for infrastructure and sustainable development projects in BRICS members and other emerging economies and developing countries and to establish the CRA with an initial size of $\$ 100$ billion. At New Delhi, the BRICS leaders requested their finance ministers to examine the feasibility of setting up a development bank and report back by the next summit. At Durban they commended the finance ministers and central bank governors for their work on the NDB and the CRA and promised to review progress on these two initiatives at the next meeting in September 2013. But they made no commitments to review the implementation of the other pledges. For both summits, compliance with the priority commitments was higher than for the rest of the commitments. 
The difference for the New Delhi Summit was not significant at +0.27 compared to +0.30 , but for the Durban Summit it was substantial at +0.45 compared to +0.60 .

The primary achievements of the Fortaleza Summit (2014) were the finalization of the decisions on the New Development Bank and the CRA. Separate documents were also issued: the Agreement on the New Development Bank, spelling out the articles of operations, and the Treaty for the Establishment of a BRICS Contingent Reserve Arrangement, setting out the terms and conditions of the CRA. Other priorities included the leaders' agreement to promote social development and contribute to defining the international agenda in this area, building on the BRICS experience in addressing the challenges of poverty and inequality. Several commitments on development were made, including the promise to work toward an inclusive, transparent and participative intergovernmental process for building a universal and integrated development agenda to eradicate poverty, and a more concrete commitment to accelerate progress in attaining the Education for All goals and education-related Millennium Development Goals by 2015. The BRICS also stressed that the development agenda beyond 2015 should build on these goals to ensure equitable, inclusive and quality education and lifelong learning for all. Given the damage done to sustainable development and economic growth by tax evasion, transnational fraud and aggressive tax planning, the BRICS affirmed their commitment to cooperate on issues related to tax administration and in international forums targeting tax base erosion and information exchange for tax purposes. However, there were no self-accountability commitments at the Fortaleza Summit. At +0.80 , the average compliance with the priority commitments was significantly higher than the average for the rest of the commitments at +0.34 .

The 2015 Ufa Summit marked beginning of the NDB and CRA operations. The leaders expressed their expectation that the NDB would approve its inaugural investment projects in early 2016. In the Strategy for BRICS Economic Partnership, the leaders directed their relevant ministries and agencies to take practical steps for efficient implementation and to assess the feasibility of developing a roadmap for BRICS trade, economic and investment cooperation for the period until 2020. They confirmed their commitment to the post-2015 Sustainable Development Goals and to South-South cooperation. For the first time in many years, the leaders' declaration made pledges on health. BRICS members agreed to work together in such areas as managing the risks related to emerging infectious diseases with pandemic potential and eradicating communicable diseases such as HIV/AIDS, tuberculosis, malaria, neglected tropical diseases, poliomyelitis and measles. The summit documents contained 130 commitments, the highest number of commitments in BRICS history, and 17 mandates for their implementation. Two mandates possessed accountability features: the sherpas were requested to report annually on the implementation of the BRICS Strategy for Economic Partnership and to review the BRICS Strategy every five years, or earlier if deemed necessary. These emerging accountability mechanisms and the repetition of commitments made at the ministerial level in the leaders' declaration can be expected to improve BRICS compliance performance. Thus there is a clear trend for higher compliance BRICS performance with priority commitments. Obviously in the absence of self-accountability mechanisms, the shared sense of urgency for collective and coordinated actions remains the main catalyst for compliance performance.

\section{Conclusion}

The research findings of this study do not support the conclusion that catalysts in commitments positively influence the compliance performance of the G20 or BRICS summit institution. On average, compliance performance on commitments without catalysts was higher both for institutions. Self-accountability is the only type of catalyst that exerted a positive effect. Timelines 
have no pronounced influence. Neither internal nor external mandates improved compliance performance. Engagement with international organizations also failed to improve compliance. Numerical targets had a negative impact. Hence, the analysis does not confirm the hypothesis that catalysts affect compliance performance. However, the evidence base confirms that the degree of influence depends on the type of the catalysts. It refutes the assumption that engagement with international organizations in a governing-in-alliance or a governing-through mode has a catalytic effect on G20 and BRICS compliance.

The analysis confirms the conclusion that a shared sense of urgency for collective action and systemic self-accountability mechanisms encourage implementation. Both factors are present in the G20 performance, where two opposite trends are observed: a decline in the proportion of commitments made in response to demand for $\mathrm{G} 20$ collective action to resolve urgent challenges and a rise in the proportion of self-accountability commitments related to G20 performance. For the BRICS, the main catalyst is a shared awareness of the demand for collective action

These two factors do not have a linear or universal effect, but they may complement and reinforce each other. As the G20 becomes increasingly institutionalized, implementation becomes a value, if not a norm, with self-accountability a safeguard for delivery.

\section{References}

G20 (2009) "Global Plan for Recovery and Reform.” London, 2 April. http://www.g20.utoronto. ca/2009/2009communique0402.html (July 2016).

G20 (2010a) “The G20 Seoul Summit Leaders’ Declaration.” Seoul, 12 November. http://www.g20.utoronto. ca/2010/g20seoul.html (July 2016).

G20 (2010b) “The G20 Toronto Summit Declaration.” Toronto, 27 June. http://www.g20.utoronto.ca/2010/ to-communique.html (July 2016).

G20 (2012a) "Los Cabos Growth and Jobs Action Plan.” Los Cabos, 19 June. http://www.g20.utoronto. ca/2012/2012-0619-loscabos-actionplan.html (July 2016).

G20 (2012b) "Policy Commitments by G20 Members.” Los Cabos, 19 June. http://www.g20.utoronto. ca/2012/2012-0619-loscabos-commitments.pdf (July 2016).

G20 (2013) “St. Petersburg Action Plan.” St. Petersburg, 6 September. http://www.g20.utoronto.ca/2013/20130906-plan.html (July 2016).

Gnath, Katharina, Stormy-Annika Mildner and Claudia Schmucker (2012) "G20, IMF and WTO in Turbulent Times: Legitimacy and Effectiveness Put to the Test.” SWP Research Paper 2012/RP 10, August. Berlin: Stiftung Wissenschaft und Politik. http://www.swp-berlin.org/fileadmin/contents/products/research_papers/2012_ RP10_Gnath_mdn_Schmucker.pdf(July 2016).

Kirton, John J. (2010) "Multilateral Organizations and G8 Governance: A Framework for Analysis.” In: John J. Kirton, Marina Larionova and Paolo Savona, eds., Making Global Economic Governance Effective: Hard and Soft Law Institutions in a Crowded World. Farnham: Ashgate. pp. 23-42.

Kirton, John J., Ella Kokotsis, Jenilee Guebert and Caroline Bracht (2016) "Compliance Coding Manual for International institutional Commitments.” March. Toronto: Global Governance Program, Trinity College, University of Toronto. http://www.g7.utoronto.ca/compliance/compliance-coding-manual-2016.pdf (July 2016). 
Contact information

12, Malaya Pionerskaya st., Office 557

115054, Moscow, Russia

Tel: +7 (495) 772-95-90*23147 and *23149

E-mail: iori@hse.ru

Web: http://iorj.hse.ru/

Actual address: 33, korp. 4, Profsoyuznaya St., Office 516

117418, Moscow, Russia

Higher School of Economics Publ. House

Postal address: 20 Myasnitskaya St., Moscow 101000, Russia

Telephone/fax: (495) 772-95-71, e-mail: id.hse@mail.ru

Passed for printing: 26.08 .2016

Format: $60 \times 881 / 8$. Offset printing.

Offset paper No. 1. Published sheets: 11,8

Number of copies: 200. Order 